\title{
Days away from Work Injury and Associated Factors among Waste Collectors in Mekelle City, Northern Ethiopia: A Cross Sectional Study
}

Mesele Bahre Abrha ( $\square$ messaybahre@gmail.com )

Mekelle University https://orcid.org/0000-0002-2585-0277

Yisak Arbise Messelle

Mekelle University

Akeza Awealom Asgedom

Mekelle University

Beyene Meressa

Mekelle University

Research

Keywords: Work injury, Absenteeism, Waste collectors, Mekelle

Posted Date: June 26th, 2020

DOI: https://doi.org/10.21203/rs.3.rs-37876/v1

License: (c) (i) This work is licensed under a Creative Commons Attribution 4.0 International License. Read Full License 


\section{Abstract}

Background: In its nature, solid waste management is a labour intensive industry, which exposes workers to numerous occupational hazards. This study was aimed to investigate the magnitude of days away from work injuries and associated factors among organized waste collectors in Mekelle city, Northern Ethiopia.

Method: A questionnaire and observation checklist based cross-sectional study design was employed from June 1 to 30, 2017. Data was analysed using SPSS for windows 20.0. Descriptive statistics and logistic regression methods were used to describe the study population and assess the association between dependent and independent variables, respectively.

Result: From the total of 279 waste collectors involved as a study participant, ten percent(10\%) of them reported at least one day away from work injuries during the last twelve months. Female were $96 \%$ less likely to be injured as compared to male ( $\mathrm{AOR}=0.04,95 \% \mathrm{Cl}$ : $0.008-0.204)$. Being married is $87 \%$ less likely to be injured as compared to being a single (AOR $=0.13095 \% \mathrm{Cl}$ : $0.027-0.621)$. The odds of injury were 4.5 times higher among those who do not use personal protective equipment as compared to their counterparts (AOR $=4.51495 \% \mathrm{Cl}: 1.684-12.095)$. Waste collectors, who had less than 1000 Birr income, were 3 times more likely to be injured than waste collectors who had greater than 1001 Birr per month income $(\mathrm{AOR}=3.00895 \% \mathrm{Cl}: 1.081-8.371$.

Conclusion: Days away from work injury among waste collectors is a public health problem and has an impact on the economic and social well-being of workers. Therefore, strengthening the provision of personal protective devices and insuring its utilization is highly recommended.

\section{Background}

Occupational injury is a major problem in many economic sectors and affects large numbers of workers $(1-4)$. About $30-50 \%$ of the worker's working place is unsafe and the majority proportion of the global workforce has no access to occupational health services which contributes to the prevalence of work related injury $(5,6)$. International labor organization (ILO) estimated that globally, 320,580 fatal injuries taken place due to occupational exposure(7).

Besides its public health impact, occupation injury has an socio-medical and socio-economic developmental problem due to lost working days, long term disabilities, reduced work ability and capacity due to partial disabilities, premature retirement from work and deaths $(2,3,7)$. Owing to occupational injury, it is estimated that each year more than six million workers are absent four or more days from their workplace(8). In sub-Saharan Africa, more than 42 million of work-related accidents cause at least three days' absence from work (9). Study done in Zambia reported from 4998 (8.1\%) study participants, 60.5\% of them reported having stayed away from work as a result work related injury (10). 
The economic cost of work related illness, injuries and death is massive at individual, enterprise, national and global levels. Roughly more than $4 \%$ of global GNP every year losses is estimated due to compensation, lost working time, interruption of production, training and retraining, medical expenses, and so on $(9,11)$. Comparing to developed nations, the economic burden will be worst for developing countries as $70 \%$ of the world working population live in (11).

In urban solid waste industry, waste is collected, transported and managed manually, which will expose waste workers to a number of occupational hazards $(8,12-17)$. Several studies depicted that working as a waste collector is associated with a high risk of occupational injuries $(15,18-25)$.

Most of accidents in waste management setting are related to the implementation of safety measures $(16,26,27)$, working condition( $2,22,28)$, environmental factors $(29,30)$, personal factor $(8,30,31)$, organizational factor(29). In solid waste workers, accident hazards originate from a variety of causes. Previous study points out those waste workers are mainly exposed to injuries from sharp objects such as glasses, scrap metals, bones, syringes, nails, spikes, and thorns(28).

Though occupational injury has profound health and economy impact, it remains neglected in developing countries, where only $5-10 \%$ of the workers have access to occupational health services (11) and occupational health research doesn't recognize the social and political context of work relations and lack political commitment to translate scientific findings into effective policies (1). As the result, information on occupational injury is not well organized, evaluated and monitored at any work setting.

In Ethiopia, there few studies done on occupational injuries(8, 22, 32), However, these occupational injury doesn't clearly indicate severity which can be indicated by the loss of workdays due to injury. More specifically, there is no comprehensive study on occupational health hazards among small scale organized micro enterprise in Mekelle city where there are a number of workers engaged in the collection of solid waste.

Therefore, the study is aimed to investigate the magnitude of day away from work injury and associated factors among organized waste collectors in Mekelle city, Northern Ethiopia

\section{Methods}

\section{Study Area and Design}

Cross-sectional study design was used to determine prevalence day away from work injuries and associated factors in Mekelle City. Mekelle is located in northern Ethiopia (783 km away from Addis Ababa). The city is located between latitude of $13^{\circ} 32^{\prime}$ north and longitude of $39^{\circ} 28^{\prime}$ with a total population of 215,546 and an annual growth rate of $5.4 \%$ is among the fastest growing cities in Ethiopia. The daily solid waste generation rate is $0.22 \mathrm{~kg} / \mathrm{c} / \mathrm{d}$. The municipality was able to collect only $33.4 \%$ of the total waste generated until recently. Currently, the solid waste collection system in the city is based on 
door to door collection of micro and small scale enterprises. In general, there are eight waste micro and small enterprises engaged in solid waste management.

\section{Population}

The study population for this study was all waste collectors engaged in solid waste collection of the city. Individual waste collectors who have a minimum of 12 months' work experience were included as study participants.

\section{Sample Size Determination}

All the waste collectors available during data collection period were taken. Henceforth, 279 individuals were involved as study participants in this study.

\section{Data Collection Procedures and Quality Control}

Structured questionnaire and observational checklist were used to collect data related to sociodemographic characteristics, occupational injury, previous occupational history and illness, smoking history, type and use of personal protective devices, training about occupational health and safety of the waste collectors.

The questionnaire was first prepared in English and translated into local language. The consistence of language translation was checked by translated back into English. Pre-test was done on $5 \%$ of the questionnaire out of the study site before data collection to check the validity. Half day training was given for data collectors and supervisors on data collection process and techniques, the purpose of the study, content and application of questionnaires. The whole data collection process was monitored and corrective measures were taken by supervisors through continuous supervision.

\section{Operational Definition}

\section{Injury}

Work related physical damage to body tissues as the result of exposure to occupational hazards.

\section{Days-away-from-work injuries}

The self-reported injuries that cause workers absent from work at least one day beyond the day of the event in the last twelve months prior the data collection.

\section{Micro and Small Enterprise}

Small scale unions that are organized by the government and involved in waste management activities.

\section{Statistical Analysis}


The collected data were entered to SPSS version 20.0 for analysis. Descriptive statistics like frequency distribution, mean, graphs were computed to explain the study population in relation to relevant variables. An association between dependent and independent variables was presented using odds ratios and $95 \%$ confidence intervals. Both Bivariate and multiple logistic regressions were used to test the association between the outcome and independent variables. Variables which had association at $\mathrm{P}<0.2$ during the bivariate analysis were a candidate to multiple logistic regressions.

\section{Result}

\section{Socio-demographic Characteristics}

A total of 279 waste collectors were participated in this study. Female waste collectors account $69 \%$ of the respondents. The mean age of the respondents was $33.70( \pm 12.245)$ years. Almost $63 \%$ of the respondents completed primary school. Almost, $93 \%$ of respondents were not permanently employed. The majority $(68.8 \%)$ of the respondents were street sweepers. Regarding income, $63 \%$ of the respondents have a monthly income ranged from 500 to 1000 Ethiopian Birr.

Work Environment and Worker's Occupational Behavior The majority (82\%) of the respondents had five and less than five years' experience and worked eight and less than eight hours per day. Out of the 279 respondents, $93.5 \%$ of them reported their workplace was not regularly supervised. Presence of hazard was observed in $82.8 \%$ of the study participant's work place. About $31 \%$ of the respondents reported that no safety training was given during their employment time. Among the respondents, $65 \%$ of them were used at least one type of personal protective equipment. Glove (64.2\%), face mask (18.3\%) and boot (33.7\%) were the commonly used type of personal equipment by the respondents. Absence of personal protective equipment $(25.8 \%)$ was the main reasons reported for not using personal protective equipment. [Table 2].......insert here

\section{Substance Use}

In the last twelve months, about $89(31.9 \%)$ and $185(66.3 \%)$ of the respondents had a history of alcohol and coffee consumption respectively. However, around $98 \%$ of the respondents never had a history of smoking and "Khat" consumption.

\section{Work Related Injury}

Of the 279 respondents, 29 (10.4\%) respondents were reported at least one day away from work injury in the last twelve months. Leg and hand were the most reported injured body part of the waste collectors.

Regarding the type of injuries, out of the respondents who had an occupational injury in the last twelve months, eighteen respondents reported abrasion type of injury, two respondents reported fracture type of injury, one respondent reported cut type of injury and one respondent reported puncture type of injury. Waste collection (11 respondents), and Loading and unloading (10 respondents) were the major activities performed during injury time of solid waste collectors. 
Table 3 shows the distribution of occupational injuries in season and days. More injuries were occurring during winter (70\%). Tuesday and Monday were the days that more injuries are occurring as it is reported by 9 and 8 respondents, respectively. Fifteen and ten respondents reported the injury were happening in the morning and at noon, respectively.

Factors Associated with Occupational Injury

Of all the variables entered in the final multivariable model fitted for occupational injuries: sex, marital status, personal protective equipment utilization and income were remained significant after adjusting for other independent factors. Female were $96 \%$ less likely to be injured as compared to male (AOR $=0.04$, $95 \% \mathrm{Cl}: 0.008-0.204$ ). Being married is $87 \%$ less likely to be injured as compared to being a single ( $\mathrm{AOR}=$ $0.13095 \% \mathrm{Cl}: 0.027-0.621)$. The odds of DAFW injury were 4.5 times higher among those who do not use personal protective equipment as compared to their counterparts (AOR $=4.51495 \% \mathrm{Cl}$ : $1.684-$ 12.095). Waste collectors, who had less than 1000 Birr income, were 3 times more likely to be injured than waste collectors who had greater than 1001 Birr per month income $(A O R=3.00895 \% \mathrm{Cl}: 1.081-8.371$.

\section{Discussion}

The magnitude of days away from work injury in this study was found to be $10.4 \%$, which is relatively lower compared to other previous studies $(8,22,33,34)$. Besides our study excluded injury that doesn't cause lost in workdays, the discrepancy might be due to the difference in environmental condition, waste collection and segregation practices, and the utilization of personal protective equipment by waste collectors.

All most all the waste pickers involved in this study had experienced an injury that made them at least one day away from their work. This is probably due to the nature of the work and manually picking important materials from unsegregated wastes without personal protective equipment, which is common practice in most of low income countries $(15,35,36)$.

Manually collecting, picking and transporting of un-segregated wastes that contains sharp objects such as tin, broken glass, bones, metal and other building materials can cause abrasion $(15,16,31,37,38)$. In study done in Addis Ababa (8), abrasion was reported as major type of injury among waste collectors. Similarly, in our study abrasion was the common type of injury reported.

In waste collection activities, legs and hands are commonly injured body parts(31, 39-42). This is due to the reason that manual loading, uploading and picking of wastes without wearing appropriate glove and shoes increase the probability of a cut, bruises and ruptures $(42,43)$. Our result is comparable with other studies (8, 33).

This study found injury is less likely to occur in female as compared to male. This study is supported by a study done on South Korea(30) and Tanzania(31). This is attributed to the job category of respondents as more women were involved in street sweeping. With respect to the marital status, being married is less likely to be injured as compared to being a single. This finding is contrary to the finding of a study done in 
Tanzania(31), where married solid waste collectors were more injured than single solid waste collectors. Based on the result, the explanation for this finding could be the married waste collectors have extra family responsibility and then they can take care of themselves.

The occurrence of occupational injuries is significantly associated with monthly salary of the workers(44). This finding is in agreement with a study conducted in Ethiopia $(8,34)$. This finding is not surprising, as individuals with higher salary have a better chance to buy and properly use personal protective equipment, if they are not provided by the organization.

Availability and utilization of personal protective equipment is one of the determinate of occupational injuries in any work setting $(8,18,34,44)$. Proper utilization of personal protective equipment such as heavy duty glove and boots will prevent a work related injury. In this study, day away from work injury is significantly associated with utilization of personal protective equipment.

Female waste collectors were higher than male waste collectors (street sweeping) in our study. This finding is supported by other studies in other part of Ethiopia $(8,22)$. The reason for this might be improving the livelihood of women is the priority issue in developing countries and subsequently, this work sector is an emerging and categorized as one of small scale enterprises in which females can involve easily and actively due the nature of the work and the societal role expectations assigned to the different genders $(45,46)$.

Self-reported data unsupported by clinical investigation were collected, which is considered as a limitation of this study. Hence, a further study on occupational injury supported by clinical investigation is necessary. Yet, despite this limitation, this study puts its significance on the magnitude of days away from work injury which indirectly indicate the severity of the injury and economical implication of the waste collectors.

\section{Conclusion}

In conclusion, this study confirms that day away from work injury among waste collectors is a public health problem and might have an economic and social well-being impact on the workers. Thus, priority has to be given to take an immediate measure. PPE utilization and monthly salary are the main determinant factors for days away from work injuries in small scale organized waste collectors. Therefore, strengthening the existing occupational health and safety services in general, and the provision of personal protective devices and ensuring its utilization in particular, are highly recommended.

\section{Acronyms And Abbreviations}

DAFWI: Days Away from Work Injury; ILO: International Labor Organization; GNP: Gross National Product; PPE: Personal Protective Equipment; SPSS: Statistical Package for Social Science; SME: Small Scale Enterprises; WHO: World Health Organization 


\section{Declarations}

\section{Ethics approval and consent to participate}

Ethical clearance was obtained from Mekelle University Ethical approval committee. Letter of permission was secured from Mekelle city municipality office and a written consent was obtained from each respondent by informing the purpose and significance of the survey.

\section{Consent for publication}

The funder has no role in making a decision for publication

\section{Availability of data and material}

The dataset contains confidential injury related data which should not be shared publicly, according to the journal ethical policy. Therefore, the data sets used and/or analysed during the current study are available from the corresponding author and can be shared on reasonable request.

\section{Competing interests}

The authors declare that they have no competing interests

\section{Funding}

This work was supported by the Mekelle University under Grant number CRPO/CHS/SM/026/09.

\section{Author's contribution}

MB conceived and designed the study, performed analysis and interpretation of data. MB and BM participated in data collection and drafted the first manuscript; YA and AA did the data entry and critical review of the subsequent draft of the manuscript. All authors read and approved the final version of the manuscript for publication to Archives of Environmental and Occupational Health Journal.

\section{Acknowledgments}

We are grateful to study participants. We would like to thank Mekelle University for financial support. Our thanks also extend to colleagues for their valuable comments.

\section{References}

1. WHO Collaborating Centres for Occupational Health. Declaration on Workers Health. 2006;1-4.

2. Cemalovic N, Rosic S, Toromanovic N. Analysis of the Causes of Occupational Injuries and Application of Preventive Measures. Mater Socio Medica. 2016;28(1):51.

3. Insurance S, Leigh JP. Illness in the United States. 2011;89(4):728-72. 
4. Thepaksorn P, Pongpanich S. Occupational injuries and illnesses and associated costs in Thailand. Saf Health Work. 2014;5(2):66-72.

5. WHO. WHO Global Plan of Action on Workers' Health Baseline for Implementation. WHO Doc Prod Serv. 2017.

6. WHO. Global strategy on occupational health for all: The way to health at work. [Internet]. Beijing, China. 1994 [cited 2020 Apr 23]. Available from:

http://www.who.int/occupational_health/publications/globstrategy/en/index1.html.

7. Taswell K, Wingfield-Digby P. Occupational injury statistics from household surveys and establishment surveys: an ILO manual on methods. Internatio. Geneva: International Labour Organization; 2008. 196 p.

8. Bogale D, Kumie A, Tefera W. Assessment of occupational injuries among Addis Ababa city municipal solid waste collectors: A cross-sectional study. BMC Public Health. 2014;14(1):1-8.

9. ILO. Fundamental principles of occupational health and safety. Second. Alli B 0., editor. Geneva: International Labour Organization; 2008. 221 p.

10. Siziya S, Muula AS, Ryan A, Rudatsikira E. Compensation patterns following occupational injuries in Zambia: results from the 2009. Labour Survey. 2010;12(12):1-8.

11. Takala J, Hämäläinen P, Saarela KL, Yun LY, Manickam K, Jin TW, et al. Global estimates of the burden of injury and illness at work in 2012. J Occup Environ Hyg. 2014;11(5):326-37.

12. Sethy S, Sothun C, Wildblood R. Municipal Solid Waste Management in Cambodia. 2014.

13. Shakya SM, Tuladhar B. State of Municipal Solid Waste Management in the Municipalities of Nepal. 2014.

14. Thi N, Thai K. Municipal Solid Waste Management in Vietnam Challenges and Solutions. 2014;35577.

15. Ziraba AK, Haregu TN, Mberu B. A review and framework for understanding the potential impact of poor solid waste management on health in developing countries. Arch Public Heal. 2016;1-11.

16. Bleck D, Wettberg W. Waste collection in developing countries - Tackling occupational safety and health hazards at their source. Waste Manag. 2012;32(11):2009-17.

17. Paiva MHP de, Albuquerque M, da CC, Latham, Bezerra EE, Sousa CF, da S A, Araújo LC e S de, et al. Occupational hazards of Brazilian solid waste workers: a systematic literature review. Rev Bras Med do Trab. 2017;15(4):364-71.

18. Sabde YD. A study of morbidity pattern in street sweepers: a cross-sectional study. Indian J Community Med. 2008;33(4).

19. Giusti L. A review of waste management practices and their impact on human health. Waste Manag. 2009;29(8):2227-39.

20. Abd EW, Wahab E, Eassa SM, Lotfi SE, Masry SA, El, Shatat HZ. Adverse Health Problems Among Municipality Workers in Alexandria (Egypt) Adverse Health Problems Among Municipality Workers in Alexandria (Egypt). 2014;(October 2015). 
21. Garrido MV, Bittner C, Harth V, Preisser AM. Health status and health-related quality of life of municipal waste collection workers - a cross-sectional survey. J Occup Med Toxicol. 2015;1-7.

22. Eskezia D, Aderaw Z, Ahmed KY, Tadese F. Prevalence and associated factors of occupational injuries among municipal solid waste collectors in four zones of Amhara region, Northwest Ethiopia. BMC Public Health. 2016;16(1):1-7.

23. Binion $E$, Gutberlet $J$. The effects of handling solid waste on the wellbeing of informal and organized recyclers: A review of the literature. Int J Occup Environ Health. 2012;18(1):43-52.

24. Aderaw Z, Engdaw D, Tadesse T. Determinants of Occupational Injury: A Case Control Study among Textile Factory Workers in Amhara Regional State. Ethiopia. 2011;2011:377.

25. Black M, Karki J, Lee ACK, Makai P, Baral YR, Kritsotakis El, et al. The health risks of informal waste workers in the Kathmandu Valley: a cross-sectional survey. Public Health. 2018;166(0):10-8.

26. Kontogianni S, Moussiopoulos N. Investigation of the occupational health and safety conditions in Hellenic solid waste management facilities and assessment of the in-situ hazard level. Saf Sci. 2017;96:192-7.

27. Lay AM, Saunders R, Lifshen M, Breslin FC, LaMontagne AD, Tompa E, et al. The relationship between occupational health and safety vulnerability and workplace injury. Saf Sci. 2017;94:85-93.

28. Jeong BY. Occupational Injuries and Deaths in Domestic Waste. 2016;0(0):1-7.

29. Battaglia M, Passetti E, Frey M. Occupational health and safety management in municipal waste companies: A note on the Italian sector. Saf Sci. 2015;72:55-65.

30. Park J, Lee J, Lee M. Occupational Health Injuries by Job Characteristics and Working Environment among Street Cleaners in South Korea. 2020.

31. Mamuya S, Badi S. Factors contributing to occupational injuries among solid waste collectors: across sectional study in a municipal in Tanzania. 2019;8(6):237-41.

32. Gizaw Z, Teka Z, Adane MM. Assessment of occupational injury and associated factors among municipal solid waste management workers in Gondar town and Bahir Dar City, northwest Ethiopia, 2012. 2014;(September 2015).

33. Ivens U, Lassen JKB. Injuries among domestic waste collectors. Am J Ind Med. 1998;33:182-9.

34. Gizaw Z, Gebrehiwot M, Teka Z, Molla M. Assessment of occupational injury and associated factors among municipal solid waste management workers in Gondar town and Bahir Dar City, northwest. J Med Med Sci. 2014;5(September):181-92.

35. Cointreau S. Occupational and environmental health issues of solid waste management. Urban Pap. 2006;57.

36. Jayakrishnan T, Jeeja M, Bhaskar R. Occupational health problems of municipal solid waste management workers in India. Int J Environ Health Eng. 2013;2(1):42.

37. Martinez CA. Infor $m$ al Waste-Pickers in Latin A m erica: Sustainable and Equitable Solutions in the Dumps. 2010. 
38. Monitoring E, Getahun T, Beyene EM, Alemayehu E, Olani DD. Municipal solid waste generation in growing urban areas in Africa: Current practices and relation to socioeconomic factors in Jimma, Ethiopia Municipal solid waste generation in growing urban areas in Africa : current practices and relation to socioecon. 2011;(October).

39. Jeong BY, Lee S, Lee JD. Workplace Accidents and Work-related Illnesses of Household Waste Collectors. Saf Health Work. 2016;7(2):138-42.

40. S. J. Occupational risks associated with solid waste management in the informal sector of Gweru, Zimbabwe. J Environ Public Health. 2016;2016.

41. Brazil H, Mol MPG, Pereira AF, Greco DB, Cairncross S, Heller L. Assessment of work-related accidents associated with waste handling in Belo. 2017.

42. Robazzi MLCC, Moriya TMFM. Garbage collectors: Occupational accidents and coefficients of frequency and severity per accident. Ann Agric Environ Med. 1997;4(September 1996):91-6.

43. Olorunnishola OA, Kidd-Taylor A, Byrd L. Occupational Injuries and Illnesses in the Solid Waste Industry: A Call for Action. NEW Solut A J Environ Occup Heal Policy. 2010;20(2):211-23.

44. Thakur P, Ganguly R, Dhulia A. Occupational Health Hazard Exposure among municipal solid waste workers in Himachal Pradesh, India. Waste Manag. 2018;78:483-9.

45. Harshey S, Sharma P. Making Waste Matter: Reimagining Urban Renewal and Advocating for Women Waste- Pickers ' Right to a Dignified Livelihood. 2014;263-83.

46. Response W, Kilby P. Waste Recycling and the Changing “ Rules of the Game.” 2013;211-26.

\section{Tables}

Table1: Socio-demographic characteristics of waste collectors in Mekelle city, June, 2017 


\begin{tabular}{|c|c|c|c|}
\hline Variable & Category & Frequency & Percent \\
\hline \multirow[t]{2}{*}{ Sex of Respondents } & Female & 194 & 69.5 \\
\hline & Male & 85 & 30.5 \\
\hline \multirow[t]{4}{*}{ Age of Respondents } & $18-25$ & 90 & 32.3 \\
\hline & $26-35$ & 79 & 28.3 \\
\hline & $36-45$ & 71 & 25.4 \\
\hline & $>45$ & 39 & 14 \\
\hline \multirow[t]{4}{*}{ Religion of Respondents } & Orthodox & 265 & 95 \\
\hline & Muslim & 10 & 3.6 \\
\hline & Catholic & 2 & 0.7 \\
\hline & Protestant & 2 & 0.7 \\
\hline \multirow[t]{4}{*}{ Educational Status of Respondents } & Primary school (1-8) & 178 & 63.8 \\
\hline & Secondary School (9-12) & 80 & 28.7 \\
\hline & Certificate and above & 2 & 0.7 \\
\hline & Can read and write & 19 & 6.8 \\
\hline \multirow[t]{4}{*}{ Marital Status } & Single & 101 & 36.2 \\
\hline & Married & 92 & 33 \\
\hline & Divorced & 65 & 23.3 \\
\hline & Widowed & 21 & 7.5 \\
\hline \multirow[t]{2}{*}{ Employment Pattern } & Permanent & 21 & 7.5 \\
\hline & Temporary & 258 & 92.5 \\
\hline \multirow[t]{2}{*}{ Job Category } & Street sweeper & 192 & 68.8 \\
\hline & Waste collectors & 87 & 31.2 \\
\hline \multirow[t]{3}{*}{ Income of Respondents } & $<500$ & 74 & 26.5 \\
\hline & $500-1000$ & 176 & 63.1 \\
\hline & $1001-1500$ & 29 & 10.4 \\
\hline
\end{tabular}

Table 2: Occupational behaviour and work environment of waste collectors in Mekelle city, June, 2017 


\begin{tabular}{|c|c|c|c|}
\hline Variable & Category & Frequency & Percentage \\
\hline \multirow[t]{2}{*}{ Working Experience } & 5 and less than 5years & 231 & 82.8 \\
\hline & Greater than 5 yeas & 48 & 17.2 \\
\hline \multirow[t]{2}{*}{ Working Hours } & 8 and less than 8 hours & 230 & 82.4 \\
\hline & Greater than 8 hours & 49 & 17.6 \\
\hline \multirow[t]{2}{*}{ Regular supervision of work place } & Yes & 18 & 6.5 \\
\hline & No & 261 & 93.5 \\
\hline \multirow[t]{2}{*}{ Presence of hazard } & Yes & 231 & 82.8 \\
\hline & No & 48 & 17.2 \\
\hline \multirow[t]{2}{*}{ Had safety training } & Yes & 89 & 31.9 \\
\hline & No & 190 & 68.1 \\
\hline \multirow[t]{2}{*}{ PPE Utilization } & Yes & 182 & 65.2 \\
\hline & No & 97 & 34.8 \\
\hline \multirow[t]{2}{*}{ Job satisfaction } & Yes & 171 & 61.3 \\
\hline & No & 108 & 38.7 \\
\hline \multirow[t]{4}{*}{ Type of PPE used } & Glove & 179 & 64.2 \\
\hline & Face Mask & 51 & 18.3 \\
\hline & Boot & 93 & 33.7 \\
\hline & Other & 92 & 33 \\
\hline \multirow[t]{3}{*}{ Reason for not using PPE } & I do not have & 9 & 3.2 \\
\hline & No provision & 72 & 25.8 \\
\hline & It doesn't need always & 9 & 3.2 \\
\hline
\end{tabular}

Table 3: Season, day and time of Injury among waste collectors in Mekelle city, June, 2017 


\begin{tabular}{|lll|}
\hline Variable & Category & Frequency \\
\hline Day of Injury & Monday & 8 \\
\cline { 2 - 3 } & Tuesday & 9 \\
\cline { 2 - 3 } & Wednesday & 1 \\
\hline Thursday & 2 \\
\hline Friday & 1 \\
\hline Saturday & 1 \\
\hline Sunday & 1 \\
\hline Don't remember & 4 \\
\hline Total & 27 \\
\hline Mime of Injury & 15 \\
\hline Morning & 10 \\
\hline Noon & 1 \\
\hline Afternoon & 17 \\
\hline Evening & 10 \\
\hline
\end{tabular}

Table 4: Factors associated with occupational injuries among municipal solid waste collectors in Mekelle City, June, 2017 


\begin{tabular}{|c|c|c|c|c|c|}
\hline \multirow[t]{2}{*}{ Variable } & \multirow[t]{2}{*}{ Category } & \multicolumn{2}{|c|}{$\begin{array}{l}\text { Occupational } \\
\text { Injury }\end{array}$} & \multirow[t]{2}{*}{$\operatorname{COR}(95 \% \mathrm{Cl})$} & \multirow[t]{2}{*}{$\operatorname{AOR}(95 \% \mathrm{Cl})$} \\
\hline & & Yes & No & & \\
\hline \multirow[t]{2}{*}{ Sex } & Male & 24 & 61 & 1 & 1 \\
\hline & Female & 5 & 189 & $\begin{array}{l}14.872(5.439- \\
40.662)\end{array}$ & $0.04(0.008-0.204)^{\star \star}$ \\
\hline \multirow[t]{3}{*}{ Age } & 18 - 30 years & 24 & 112 & $\begin{array}{l}7.500(1.719- \\
32.720)\end{array}$ & $\begin{array}{l}0.774(0.052- \\
11.563)\end{array}$ \\
\hline & 31 - 40 years & 3 & 68 & $1.544(0.250-9.531)$ & $\begin{array}{l}2.070(0.205- \\
20.945)\end{array}$ \\
\hline & Above 41years & 2 & 78 & 1 & 1 \\
\hline \multirow[t]{4}{*}{ Marital Status } & Single & 23 & 78 & 1 & 1 \\
\hline & Married & 3 & 89 & $0.114(0.033-0.395)$ & $\begin{array}{l}0.130(0.027- \\
0.621)^{\star \star}\end{array}$ \\
\hline & Divorced & 2 & 63 & $0.108(0.024-0.474)$ & $0.666(0.082-5.405)$ \\
\hline & Widowed & 1 & 20 & $0.170(0.022-1.332)$ & $\begin{array}{l}1.201(0.092- \\
15.611)\end{array}$ \\
\hline \multirow[t]{2}{*}{ Job category } & $\begin{array}{l}\text { Street } \\
\text { Sweepers }\end{array}$ & 6 & 186 & 1 & 1 \\
\hline & $\begin{array}{l}\text { Waste } \\
\text { Collectors }\end{array}$ & 23 & 64 & $\begin{array}{l}11.141(4.342- \\
28.586)\end{array}$ & $\begin{array}{l}1.289(0.145- \\
11.469)\end{array}$ \\
\hline \multirow{2}{*}{$\begin{array}{l}\text { Job } \\
\text { satisfaction }\end{array}$} & Satisfied & 12 & 159 & 1 & 1 \\
\hline & Not satisfied & 17 & 91 & $2.475(1.132-5.414)$ & $1.288(0.451-3.682)$ \\
\hline \multirow{2}{*}{$\begin{array}{l}\text { PPE } \\
\text { Utilization }\end{array}$} & Yes & 13 & 173 & 1 & 1 \\
\hline & No & 16 & 77 & $2.765(1.268-6.030)$ & $\begin{array}{l}4.514(1.684- \\
12.095)^{\star \star}\end{array}$ \\
\hline \multirow[t]{2}{*}{ Income } & $\begin{array}{l}\text { Less than } \\
1000\end{array}$ & 19 & 110 & $2.418(1.081-5.411)$ & $\begin{array}{l}3.008(1.081- \\
8.371)^{\star \star}\end{array}$ \\
\hline & $\begin{array}{l}1001 \text { and } \\
\text { above }\end{array}$ & 10 & 140 & 1 & 1 \\
\hline \multirow{2}{*}{$\begin{array}{l}\text { Working } \\
\text { Hours }\end{array}$} & $<=8$ Hours & 20 & 210 & 1 & 1 \\
\hline & $>8$ Hours & 9 & 40 & $\begin{array}{l}2.362(1.003- \\
5.562)^{\star}\end{array}$ & $1.279(0.456-3.590)$ \\
\hline \multirow{2}{*}{$\begin{array}{l}\text { Alcohol } \\
\text { Drinking }\end{array}$} & Yes & 12 & 77 & $1.586(0.722-3.481)$ & $1.724(0.607-4.892)$ \\
\hline & No & 17 & 174 & 1 & 1 \\
\hline
\end{tabular}




$$
\text { No }
$$

17

77

1

1

* Significant at $P<0.05$ for $C O R$, ** Significant at $P<0.05$ for $A O R$. PPE $=$ Personal protective Equipment, COR - Crude Odds Ratio, AOR - Adjusted Odds Ratio, Cl - Confidence Interval, 1 Reference

\section{Figures}

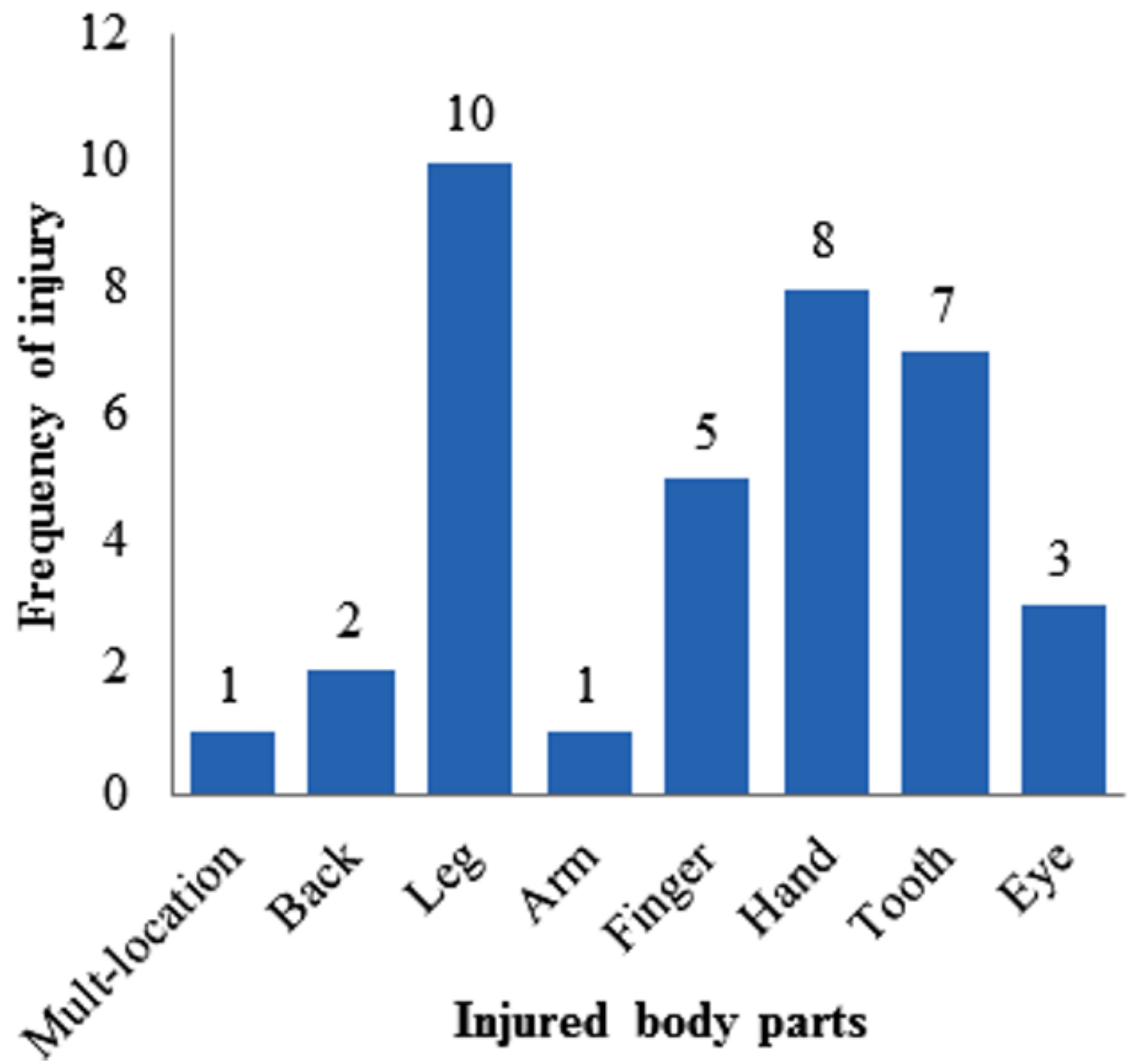

Figure 1

Injured body part of waste collectors in Mekelle City, 2017 


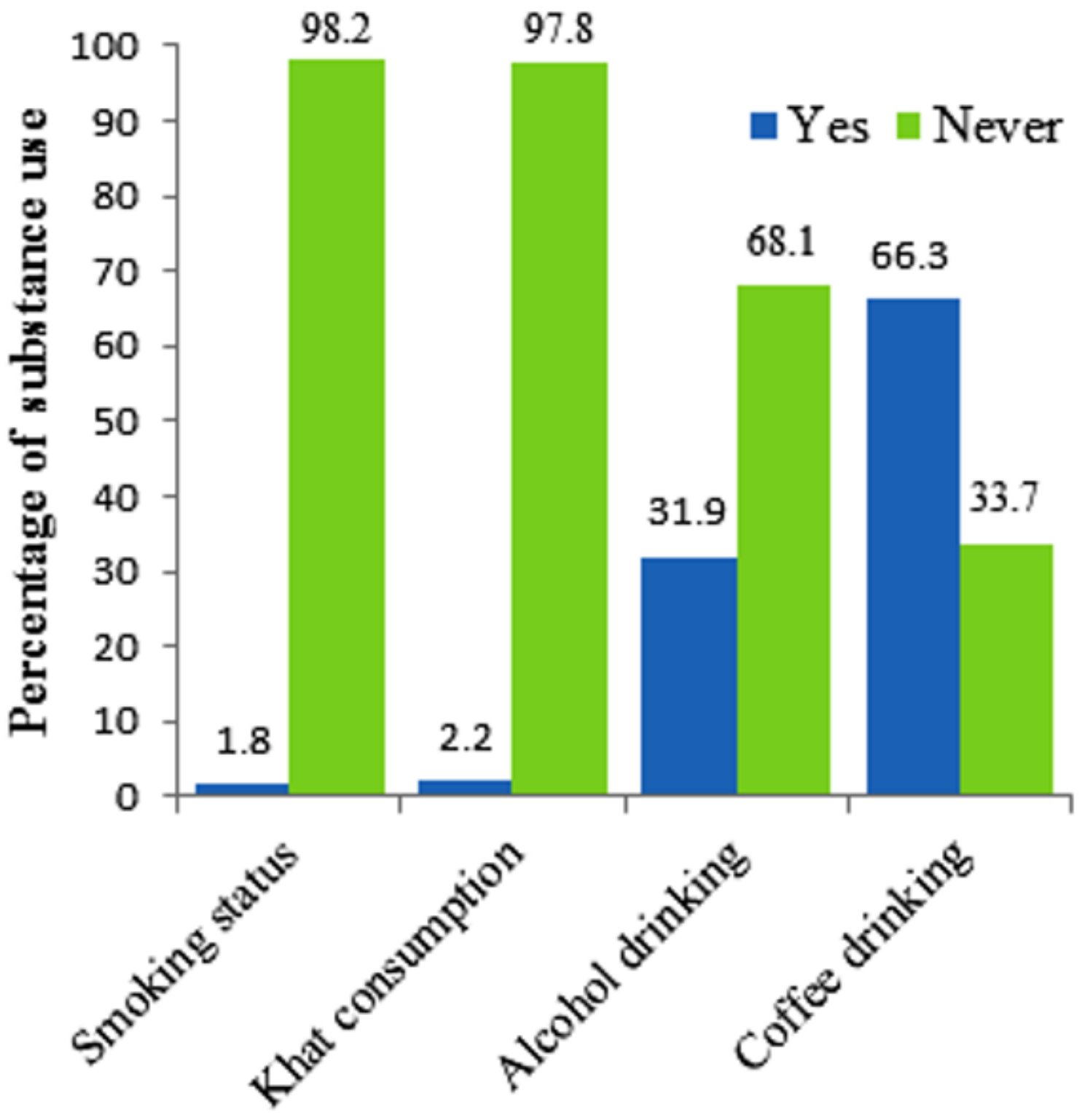

Figure 2

Substance use of waste collectors in Mekelle City, 2017

\section{Supplementary Files}

This is a list of supplementary files associated with this preprint. Click to download.

- CoverletterBMCOMT.doc 